\title{
ТАКСОНОМИЧЕСКИЙ СОСТАВ И ОРГАНИЗАЦИЯ МИКРОБНОГО СООБЩЕСТВА ДЕРНОВО-ПОДЗОЛИСТЫХ ПОЧВ ПОСЛЕ ВНЕСЕНИЯ СОЛОМЫ ЗЕРНОВЫХ КУЛЬТУР И ИСПОЛЬЗОВАНИЯ ПРЕПАРАТА БАРКОН*
}

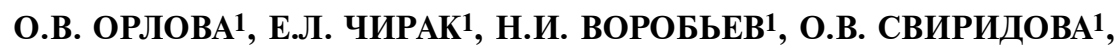 \\ Т.О. ЛИСИНА', Е.Е. АНДРОНОВ1, 2, 3
}

\begin{abstract}
Современная концепция воспроизводства почвенного органического вещества требует закрепления углерода растительных остатков в почве посредством образования устойчивых органических соединений. В этой связи важна роль биопрепаратов, ускоряющих разложение соломы. В настоящем исследовании впервые установлено, что инокуляция соломы препаратом Баркон (комплексная ассоциация микроорганизмов, разработанная во Всероссийском НИИ сельскохозяйственной микробиологии) способствует формированию деструктивных микробных биосистем с набором наиболее эффективных микроорганизмов из почвенного сообщества и упорядоченным действием по разложению растительных остатков соломы. Показано, что наибольшее влияние на состав микробных сообществ, ведущих разложение соломы, оказывают свойства почвы, а не биопрепарат, вид или глубина заделки соломы. Целью работы была оценка таксономического состава почвенного микробного сообщества, разлагающего солому зерновых культур, и роли микроорганизмов, входящих в состав биопрепарата Баркон, в изменении микробиома. В полевом и лабораторных опытах изучали микробные сообщества пахотных дерново-подзолистых почв, разлагающие солому зерновых культур. Солому (ржаная, пшеничная и овсяная) измельчали и инокулировали биопрепаратом Баркон. Функционирование микробного сообщества оценивали по количеству и активности микроорганизмов, агрохимическим показателям почвы. Состав бактериального сообщества почв определяли высокопроизводительным секвенированием библиотек гена $16 \mathrm{~S}$ рРНК. Скорость разложения соломы контролировалось соотношением в ней C:N, которая составила ряд ржаная солома < пшеничная < овсяная. Применение Баркона увеличило скорость разложения соломы на 18-42 \% по сравнению с микрофлорой почвы к 3 мес компостирования. Биопрепарат оказался более эффективен при заделке соломы в слой 0-5 см, чем на 9-12 см. Влияние Баркона на численность, биомассу микроорганизмов и дыхание было малозаметно на фоне роста этих показателей при внесении соломы. Отсутствие роста эмиссии углекислоты с увеличением скорости разложения соломы при внесении Баркона свидетельствовало о секвестрации углерода в почве. Обработка биопрепаратом способствовала формированию микробных деструктивных сообществ с наибольшей эффективностью преобразования соломы и перевода ее в лабильные органические соединения, а затем и в гумусовые вещества почвы. Применение Баркона по сравнению с внесением неинокулированной соломы повышало содержание общего углерода в почве на 4,8-18,4 \%. На состав микробных сообществ, ведущих разложение, действовали все изученные факторы (почва, солома, биопрепарат, глубина заделки и время разложения), при этом наиболее значимым был вид почвы. В более кислых дерново-подзолистых почвах при равном содержании гумуса в таксоне Acidobacteria преобладали 1-я и 2-я группы, при величине рН близкой к нейтральной преобладала 6-я группа. Индикатором внесения соломы для дерново-подзолистой почвы во всех опытах был рост числа актинобактерий из семейства Micrococcaceae, особенно в вариантах с инокуляцией соломы биопрепаратом Баркон. При разложении соломы в почве по сравнению с незаделанной наблюдали некоторое ослабление действия Баркона на образование гумификационной трофической цепи, о чем свидетельствовало отсутствие прироста лабильных гумусовых веществ. На основании расширенных таксономических данных о составе почвенного микробного сообщества было установлено, что минорные групाы микроорганизмов участвуют наравне с мажорными в образовании сетевых фрактальных структур.
\end{abstract}

Ключевые слова: микробное сообщество, солома, биопрепараты, Баркон, индекс фрактальных структур.

Разложение растительных остатков и формирование устойчивого к воздействию микроорганизмов органического вещества (гумуса) в пахот-

\footnotetext{
${ }^{*}$ Исследования выполнены с использованием оборудования ЦКП «Геномные технологии, протеомика и клеточная биология» ВНИИСХМ. Работы были проведены за счет финансовой поддержки гранта РНФ 18-16-00073.
} 
ных почвах играет важную роль в глобальном круговороте углерода в биосфере. Использование соломы в качестве органического удобрения приобретает существенное значение во всем мире, особенно в связи с развитием технологии no-till (1-5). Например, из-за резкого сокращения в России ресурсов, необходимых для традиционных органических удобрений, потребность в них для воспроизводства гумуса почв может быть удовлетворена лишь на 17-20\%. Известен положительный эффект от внесения соломы на питательный режим, физическое состояние почв, процессы гумусообразования, численность и активность почвенных микроорганизмов (2, 3, 5-7). Однако солома используется недостаточно по причине ее длительного разложения, при этом в почве создается дефицит минерального азота и выделяются фитотоксичные соединения, накапливаются фитопатогены. Решением может стать обработка соломы биопрепаратами для ускорения ее разложения и исключения возможных негативных последствий, что особенно важно для технологии no-till (8-10). Без обработки соломы специальными микроорганизмами лишь 10-20\% ее преобразуется в гумус при внесении в почву. Однако современная агроэкологическая концепция воспроизводства почвенного органического вещества (ПОВ) предполагает закрепление в почве углерода органических субстратов (секвестрация) со снижением их минерализации до $\mathrm{CO}_{2}(1,11)$, поэтому важно, чтобы биопрепараты для биодеградации соломы усиливали включение углерода пожнивных остатков в почвенное органическое вещество $(2,6,12)$.

Одной из актуальных задач в условиях нестабильного климата и нарастающей деградации почв становится управление биологической составляющей почвы с целью увеличения производства сельскохозяйственной продукции, поскольку возможности химизации земледелия и «зеленой революции» снижаются (12). Значимость биоразнообразия и суммарной деятельности микроорганизмов для функционирования почв в целом хорошо изучена, но недостаточно исследовано влияние на биологические процессы наличия и соотношения определенных видов и родов микроорганизмов (таксономическая структура), а также самоорганизации микробного сообщества в конкретной почвенной разности (13-16).

Изучение закономерностей формирования структуры микробного сообщества и его взаимосвязи со свойствами и функционированием почвы - одно из важнейших направлений современной науки $(12-14,16,17)$. Задачу осложняет так называемая избыточность микробного комплекса, когда одну функцию (разложение целлюлозы, фиксация азота, денитрификация) осуществляют многие микроорганизмы. Уменьшение численности или исчезновение какого-либо вида микроорганизмов может не сказаться на общем характере процесса в почве (определенной почвенной функции), поскольку их роль переходит к другим (13). По этой причине состав почвенного микробного сообщества не определяют при оценке питательного режима почв, расчете планируемого урожая или составлении моделей крупномасштабных циклов в стабильных условиях $(13,14)$. Однако в настоящее время, когда нормой становятся резкие изменения климата в течение сезона (аномальное тепло или холод, засуха или избыток осадков) на фоне деградации почв, информация о составе и структуре микробного сообщества может снизить неопределенность предсказаний, касающихся результата биодеградации растительных остатков и даже прогноза урожая $(13,14,16)$.

Разложение растительных остатков в почве определяется многими факторами (химический состав, физические свойства почв, гидротермические условия), поэтому наблюдаются значительные различия в скорости 
процесса, качестве конечных продуктов, коэффициентах гумификации и других показателях $(1,18-20)$. В настоящее время существуют три основных гипотезы о влиянии биологического фактора и химического состава на конечный результат биотрансформации растительных остатков (18). Согласно химической гипотезе, независимо от исходного состава остатков и микробного деструкционного сообщества, на конечной стадии трансформации будут получены одинаковые соединения (например, гумус одного типа). По другой гипотезе, в зависимости от начального химического состава растительных остатков получаются различные гумусовые вещества. Согласно третьей гипотезе, соединения образуются в зависимости от состава микробного сообщества, ведущего разложение.

Один из способов контролировать состав микробного сообщества, разлагающего солому, - внесение биопрепаратов. Интродуцированные микроорганизмы часто работают только на начальном этапе, а затем их количество снижается, и состояние микробоценоза возвращается к исходному $(21,22)$. Однако существует вариант, когда изменения в составе микробного сообщества после внесения биопрепарата сохраняются до конца разложения. Последнее возможно не только как результат прямого воздействия количества внесенных микроорганизмов, но и за счет способности биопрепарата изменять связи между ними, составляя трофические цепи по-новому. В обоих случаях возможно получение на выходе субстратов, различающихся количественно и качественно. Этот вопрос изучен недостаточно, хотя очень важен для оценки направленности почвеннобиологических процессов и роли повторного внесения биопрепарата (22).

Препарат Баркон (Всероссийский НИИ сельскохозяйственной микробиологии) представляет собой ассоциацию микроорганизмов, осуществляющую деструкцию лигно-целлюлозных субстратов и последующую их трансформацию в гумусовые вещества (23). Использование препарата оказывает стимулирующее действие на микробиологические процессы трансформации соломы, увеличивая численность микроорганизмов, микробную биомассу, коэффициент гумификации соломы, устраняет ее фитотоксичность $(6,23-25)$. При обработке соломы (стерни) Барконом без заделки в почву микроорганизмы, участвующие в трансформации растительных остатков, образуют гумификационную трофическую цепь, обеспечивая более эффективное включение в гумусообразовательные процессы как внесенных, так и нативных микроорганизмов.

В настоящем исследовании впервые установлено, что инокуляция соломы Барконом способствует формированию деструктивных микробных биосистем с набором наиболее эффективных микроорганизмов из почвенного сообщества и упорядоченным действием по разложению растительных остатков соломы. Показано, что наибольшее влияние на состав микробных сообществ, ведущих разложение соломы, оказывают свойства почвы, а не биопрепарат, вид или глубина заделки соломы.

Целью работы была оценка таксономического состава почвенного микробного сообщества, разлагающего солому зерновых культур, и роли микроорганизмов, входящих в состав биопрепарата Баркон, в изменении микробиома.

Методика. В лабораторных и полевом опытах изучали состав и функционирование микробного сообщества пахотных дерново-подзолистых почв при внесении соломы зерновых культур, инокулированной биопрепаратом Баркон (23). Солому, измельченную на кусочки (1-2 см), обрабатывали препаратом согласно рекомендациям разработчиков (1 мл препарата +25 мл воды на 10 г сухой соломы). Контролем служили вари- 
анты без внесения соломы (абсолютный контроль) и с соломой, обработанной водой.

В лабораторном опыте 1 солому мягкой пшеницы (зольность $3,5 \pm 0,2 \%, \mathrm{~N}-0,7 \pm 0,03 \%, \mathrm{C:N}-69)$ инокулировали биопрепаратом Баркон или почвенной суспензией из 1 разведения (10 г почвы в 90 мл воды) и компостировали вне почвы в течение 1 мес. В почву, отобранную из пахотного горизонта дерново-подзолистой почвы (Ленинградская обл., п. Белогорка; $\left.\mathrm{C}_{\text {гум. }}-1,27 \pm 0,02 \%, \mathrm{~N}_{\text {обш. }}-0,11 \pm 0,003 \%, \mathrm{pH}_{\text {сол }} 4,92 \pm 0,03\right)$, вносили прокомпостированную солому из расчета 3 г/кг почвы, равномерно перемешивая. Опыт проводили в стеклянных сосудах объемом 250 мл, при постоянной влажности 60 \% ППВ и температуре $25 \pm 2{ }^{\circ} \mathrm{C}$. Продолжительность компостирования с почвой составляла 3 мес, повторность -2 сосуда на каждый срок анализа, последний срок -3 сосуда.

В лабораторном опыте 2 пластиковые сосуды объемом 1,5 л наполняли окультуренной дерново-подзолистой почвой из пахотного горизонта (г. Санкт-Петербург-Пушкин, совхоз «Детскосельский»; $\mathrm{C}_{\text {гум. }}-$ $\left.4,02 \pm 0,06 \%, \mathrm{~N}_{\text {общ. }}-0,316 \pm 0,02 \%, \mathrm{pH}_{\text {сол. }} 5,63 \pm 0,01\right)$. Солому ржи (зольность $3,4 \pm 0,04 \%, \mathrm{~N}-0,25 \pm 0,02 \%, \mathrm{C}: \mathrm{N}-193)$ обрабатывали Барконом или водой и через 1 ч вносили в сосуды из расчета 3 г/кг почвы. Исследовали два варианта заделки соломы: поверхностный (0-3 см) и глубинный (9-12 см). Повторность опыта 5-кратная, длительность проведения - 62 сут при постоянной влажности $60 \%$ ППВ и температуре $25 \pm 2{ }^{\circ} \mathrm{C}$. В статье приведены данные по 5 вариантам из 13.

В полевом опыте 3 солому овса (зольность 4,9\%, $\mathrm{N}-1,40 \pm 0,01 \%$, $\mathrm{C}: \mathrm{N}$ - 34) обрабатывали Барконом или водой, перемешивали с почвой $\left(\mathrm{C}_{\text {гум. }}-1,96 \%, \mathrm{~N}_{\text {общ. }}-0,194 \%, \mathrm{pH}_{\text {сол. }}\right.$ 5,62) из расчета 3 г/кг, помещали в капроновые мешочки и укладывали в почву на глубину 0-5 и 10-15 см (опытное поле Всероссийского НИИ сельскохозяйственной микробиологии, г. Пушкин). Повторность 9-кратная, длительность опыта -1 мес.

Анализы соломы и почвы (из смешанного образца) проводили общепринятыми методами $(26,27)$ в 3-5-кратной повторности. Содержание неразложившейся соломы в почве определяли методом флотации в 0,5 н. $\mathrm{Na}_{2} \mathrm{SO}_{4}(28)$, количество общего углерода - посредством мокрого озоления с бихроматом калия, лабильного водорастворимого органического углерода - по методике Э. Шульц (29). Подвижные гумусовые соединения из почв выделяли 0,1 н. пирофосфатом $\mathrm{Na}(\mathrm{pH} 7,0$ или 10,0). Содержание углерода в вытяжках оценивали на спектрофотометре Ultraspec («LKB», Швеция) при $\lambda=340$ нм (30). Дыхание почвы измеряли на газовом хроматографе Цвет 110 (ОАО «Цвет», Россия), детектор - катарометр, газ-носитель - гелий. Микробную биомассу в почве определяли методом субстрат-индуцированного дыхания (31) как суммарную (грибы + бактерии) и грибную биомассу (обработка стрептомицином и рифампицином, 16 мг антибиотика на 1 г почвы). В опыте 1 определяли только грибную биомассу, в опыте 3 - только численность грибов. Азот и углерод микробной биомассы оценивали регидратационным методом (32). Численность физиологических групп микроорганизмов (аммонифицирующие, амилолитические, целлюлозоразлагающие, гумусразлагающие, микромицеты) учитывали при посеве почвенной суспензии на плотные питательные среды (33).

Структуру бактериального сообщества почв определяли с применением высокопроизводительного секвенирования библиотек гена $16 \mathrm{~S}$ рРНК для отдельных сроков: 2 мес для лабораторных опытов (без повторностей, из смешанных образцов по вариантам), 3 и 17 сут в слое 0-5 см для полевого опыта (повторность 3-кратная). 
Таксономический состав бактериального сообщества устанавливали с применением высокопроизводительного секвенирования библиотек гена $16 \mathrm{~S}$ рРНК. Для этого выделяли из почвы ДНК с использованием наборов MoBio («Qiagen», Германия) (34), библиотеки готовили с помощью ПЦР с универсальными праймерами для гена 16S pPHK F515 и R806 (35). Секвенирование выполняли на приборе GS Junior («Roche», США), результаты обрабатывали в программе QIIME (36).

Биоразнообразие микробных сообществ оценивали по индексу разнообразия Шеннона и коэффициенту сходства Серенсена-Чекановского. При обработке в программе Statistica v6 («StatSoft, Inc.», США) использовали стандартные методы многомерной статистики: метод главных компонент, дисперсионный, корреляционный, фрактальный анализ, графанализ. С помощью оригинальных компьютерных программ проводили необходимые вычисления, использующие процедуры дисперсионного, корреляционного и фрактального анализов (37-40). В таблицах и тексте приведены средние значения $(M)$ с доверительными интервалами при уровне значимости $\mathrm{p} \leq 0,05\left(t_{0,05} \times \mathrm{SEM}\right)$. Для сравнения библиотек (с малыми частотами) оценивали вероятность того, что частота членства в таксоне будет одинаковой для двух библиотек (41).

Вероятность наблюдаемой разницы (значимость) в присвоении к таксону Т оценивали по формуле:

$$
p(y \mid x)=\left(\frac{N_{2}}{N_{1}}\right)^{y} \frac{(x+y) !}{x ! y !\left(1+\frac{N_{2}}{N_{1}}\right)^{(x+y+1)}},
$$

где $N_{1}$ и $N_{2}$ - общее количество последовательностей для библиотек 1 и 2 , $x$ и $y$ - количество последовательностей, назначенных $\mathrm{T}$, соответственно из библиотек 1 и 2. Одно из основополагающих предположений для этого уравнения состоит в том, что $x$ и $y$ малы относительно $N_{1}$ и $N_{2}$ (менее $5 \%$ от общего числа), а $N_{1}$ и $N_{2}$ являются относительно большими (более 500).

Результаты. Поскольку связь между содержанием азота в растительных остатках и скоростью их биотрансформации $(44,43)$ общеизвестна, то, скорее всего, существенные различия в убыли соломы в разных опытах связаны именно с содержанием в ней азота. Влияние состава микробного сообщества на скорость биодеградации в такой степени маловероятно: убыль по массе за 1 мес для пшеничной соломы (опыт 1) при постоянных гидротермических условиях составляла 2,6-3,5 \%, для соломы овса в полевых условиях (опыт 3) - от 20,0 до 31,8 \% при близких значениях содержания общего углерода в почве. Медленнее всего разлагалась ржаная солома (опыт 2): за 2 мес потеря ее массы была сопоставима с показателем за 1 мес для пшеничной.

За 1 мес компостирования почвы с соломой применение Баркона не оказывало статистически значимого влияния на скорость разложения соломы, независимо от ее вида, глубины заделки и плодородия почвы. Разложение под влиянием биопрепарата существенно ускорялось только к 3-му мес (опыты 1 и 2): потери массы соломы были на 18-42 \% выше по сравнению с нативной почвенной микрофлорой. В опыте 2 была выявлена эффективность Баркона при биодеградации в верхних слоях почвы: убыль соломы в слое 0-3 см оказалась больше на 14,8 \%, а в слое 9-12 см меньше на 7,6 \% относительно варианта с нативной микрофлорой. Разложение соломы в полевых условиях также протекало несколько быстрее в слое 0-5 см (убыль соломы 30,8-31,8 \%), чем в нижнем слое (20,0-30,0 \%). Причиной меньшей эффективности глубокой заделки соломы, инокулированной Барконом, может быть то, что в состав препарата входят аэробные 
микроорганизмы $(23,24)$. При создании в нижних слоях факультативно анаэробных условий (в отдельных нишах), в том числе в результате активности микроорганизмов, Баркон работает хуже, а за счет изменения трофических связей микробного сообщества даже ухудшает ситуацию относительно варианта без биопрепарата.

В опыте 1 с предварительным компостированием пшеничной соломы применение Баркона за 30 сут увеличило образование водорастворимых гумусоподобных соединений относительно варианта с нативной

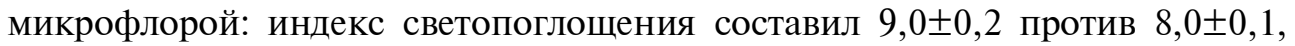

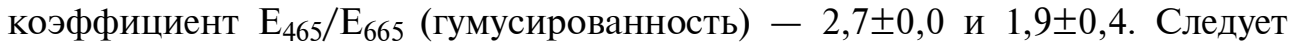
отметить, что как в контроле, так и под действием Баркона одинаково из-

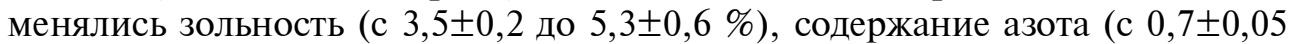
до $1,07 \pm 0,08 \%$ ), фосфора (с $0,06 \pm 0,0$ до $0,16 \pm 0,03 \%$ ), соотношение C:N (с 69 до 28). Именно с влиянием Баркона при предварительном компостировании мы связываем повышение содержания новообразованных лабильных гумусовых веществ на 25,6 \% в опыте 1 по сравнению с их количеством при применении почвенного инокулюма (табл. 1). В варианте солома + Баркон при разложении шло образование гумусоподобных соеди-

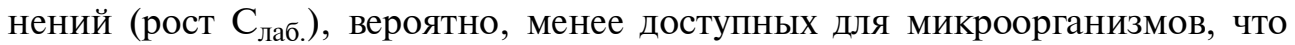
и приводило к увеличению содержания общего углерода в почве. Напротив, в варианте солома + почвенный инокулюм биомасса микроорганизмов возрастала на 67,4 \% (табл. 2) и после отмирания из-за узкого соотношения C:N $(3,4-5,8)$ в меньшей степени включалась в гумус. Кроме того, в этом варианте либо микробное сообщество усиленно разлагало не только солому, но и лабильные гумусовые вещества, либо их образовывалось меньше, в результате чего количество было ниже даже относительно контроля. Поскольку биомасса микроорганизмов характеризовалась низким C:N, гумусовые вещества, возможно, содержали больше азота, что выразилось в росте содержания общего азота в почве.

1. Агрохимические характеристики дерново-подзолистой почвы при внесении соломы и использовании биопрепарата Баркон $\left(M \pm t_{0,05} \times \mathrm{SEM}\right)$

\begin{tabular}{|c|c|c|c|c|c|}
\hline \multirow[t]{2}{*}{ Вариант } & $\mathrm{C}_{\text {общ. }} \%$ & $\mathrm{~N}_{\text {общ., } \%}$ & $\begin{array}{l}\text { Сумма N-мин., } \\
\text { мг/кг }\end{array}$ & $\left|\begin{array}{l}\mathrm{C}-\mathrm{CO}_{2}, \\
\mathrm{M \Gamma} \cdot \mathrm{K \Gamma}^{-1} \cdot \mathrm{cyT}^{-1}\end{array}\right|$ & $\begin{array}{l}\text { С-лабильный } \\
\text { гумус, мг/кг }\end{array}$ \\
\hline & \multicolumn{2}{|c|}{ в конце опыта } & \multicolumn{3}{|c|}{ среднее за опыт } \\
\hline \multicolumn{6}{|c|}{ Оп т т 1 (л абораторны й) } \\
\hline Контроль & $1,24 \pm 0,02$ & $0,106 \pm 0,003$ & $48,7 \pm 3,0$ & $8,6 \pm 1,3$ & $699 \pm 25$ \\
\hline Солома + почвенный & & & & & \\
\hline инокулюм & $1,25 \pm 0,05$ & $0,111 \pm 0,001$ & $19,8 \pm 0,2$ & $23,6 \pm 1,8$ & $636 \pm 51$ \\
\hline Солома + Баркон & $1,48 \pm 0,06$ & $0,106 \pm 0,005$ & $25,7 \pm 1,0$ & $25,8 \pm 0,9$ & $737 \pm 55$ \\
\hline \multicolumn{6}{|c|}{ Оп т т 2 (л абораторны й) } \\
\hline Контроль & $3,78 \pm 0,05$ & $0,313 \pm 0,001$ & $26,9 \pm 0,8$ & $8,8 \pm 0,1$ & $7250 \pm 120$ \\
\hline Солома, 0-3 см & $3,83 \pm 0,04$ & $0,310 \pm 0,001$ & $22,4 \pm 0,8$ & $17,7 \pm 1,6$ & $8110 \pm 320$ \\
\hline Солома, 9-12 см & $3,81 \pm 0,14$ & $0,306 \pm 0,010$ & $18,1 \pm 1,7$ & $13,8 \pm 0,8$ & $7620 \pm 280$ \\
\hline Солома + Баркон, 0-3 см & $3,84 \pm 0,03$ & $0,305 \pm 0,010$ & $22,9 \pm 0,0$ & $20,7 \pm 1,9$ & $6790 \pm 10$ \\
\hline Солома + Баркон, 9-12 см & $3,89 \pm 0,08$ & $0,307 \pm 0,010$ & $21,8 \pm 1,5$ & $15,2 \pm 3,2$ & $7040 \pm 500$ \\
\hline \multicolumn{6}{|c|}{ О п ы т 3 (п ол е в о й) } \\
\hline Контроль, 0-5 см & $1,85 \pm 0,05$ & $0,178 \pm 0,001$ & $15,3 \pm 0,1$ & $8,4 \pm 1,8$ & $1354 \pm 5$ \\
\hline Контроль, 10-15 см & $1,88 \pm 0,01$ & $0,178 \pm 0,001$ & $24,6 \pm 1,0$ & $6,6 \pm 1,0$ & $1335 \pm 22$ \\
\hline Солома, 0-5 см & $1,98 \pm 0,05$ & $0,187 \pm 0,002$ & $15,3 \pm 0,1$ & $22,6 \pm 3,9$ & $1403 \pm 7$ \\
\hline Солома, $10-15$ см & $1,89 \pm 0,09$ & $0,167 \pm 0,002$ & $17,8 \pm 1,0$ & $27,4 \pm 3,7$ & $1413 \pm 9$ \\
\hline Солома + Баркон, 0-5 см & $2,13 \pm 0,08$ & $0,179 \pm 0,001$ & $19,5 \pm 0,1$ & $30,0 \pm 2,3$ & $1369 \pm 14$ \\
\hline Солома + Баркон, 10-15 см & $1,98 \pm 0,08$ & $0,182 \pm 0,002$ & $24,6 \pm 2,0$ & $25,3 \pm 2,0$ & $1357 \pm 22$ \\
\hline
\end{tabular}

При заделке соломы в почву сразу после обработки Барконом (опыты 2 и 3) не наблюдали роста новообразованных гумусовых соединений (см. табл. 1), хотя нельзя сделать однозначный вывод, что это не было связано с типом соломы. Тем не менее применение Баркона повышало 
содержание общего углерода в почве относительно вариантов без биопрепарата за счет усиления процессов трансформации соломы, в том числе гумификационных. Например, комплексный показатель гумификации (44) при внесении соломы (опыт 2) в контроле составил 2,87, в варианте с биопрепаратом - 3,21. Баркон несколько ослабил негативные последствия внесения соломы на содержание минеральных форм азота в почвах с низким содержанием органического вещества (опыты 1 и 3). Это можно рассматривать как преимущество Баркона, поскольку его использование не требует обязательного внесения минерального азота для разложения соломы $(2,3)$, что особенно ценно, так как обычно биопрепарат применяется после уборки зерновых, когда азот не нужен для растений.

Внесение соломы ожидаемо увеличивало дыхание микроорганизмов во всех опытах (см. табл. 1). Влияние Баркона на этот показатель на фоне неинокулированной соломы было несущественным. Только в опыте 2 отмечали тенденцию к росту выделения углекислоты из почвы. Усиления дыхания не наблюдали и в экспериментах с Барконом, проведенных другими исследователями (6).

На почвах с низким содержанием общего углерода (опыты 1 и 3) внесение соломы увеличило численность основных групп микроорганизмов в 2 раза и более (табл. 2), что согласуется с данными о большей эффективности удобрений и препаратов на бедных почвах $(2,12,45)$. При внесении соломы происходит кратковременная вспышка развития r-стратегов $(2,46)$ : в опыте 3 на 3-и сут наблюдали рост численности аммонифицирующих и амилолитических микроорганизмов, который прекращался уже на 17-е сут. Обработка соломы препаратом не привела к существенным изменениям численности целлюлозолитических микроорганизмов, за исключением опыта 2. В опыте 3 влияние биопрепарата было еще более слабым и не носило постоянного характера. Так, на 17-е сут при внесении Баркона наблюдали некоторое снижение численности целлюлозолитических микроорганизмов в слое $0-5$ см.

Баркон влиял на сукцессию микроорганизмов. Так, в опыте 1 коэффициент корреляции между численностью гумусразлагающих микроорганизмов и содержанием остаточной соломы в вариантах с Барконом и почвенным инокулюмом менял направленность $(-0,87$ против 0,71$)$. Значительное влияние на тесноту и направленность связи между динамикой физиологических групп и количеством оставшейся в почве соломы наблюдали и для других микроорганизмов: коэффициенты корреляции для вариантов с Барконом и без составляли соответственно 0,20 и -0,78 (целлюлозоразлагающие), $-0,38$ и 0,36 (амилолитические).

Во всех опытах не было обнаружено существенного влияния внесения соломы, препарата и глубины внесения на численность и/или биомассу грибов (см. табл. 2). Возможно, это связано с тем, что в пахотных почвах в процессе разложения растительных остатков возрастает роль бактерий (45). В наших опытах в исследуемые сроки наблюдали некоторое возрастание численности бактерий, в то время как численность грибов менялась незначительно или снижалась: их доля от суммарной биомассы составляла от 14 до $22 \%$. При внесении соломы увеличивалась не только численность, но и биомасса почвенных микроорганизмов, а влияние обработки биопрепаратом было несущественным (см. табл. 2). Под действием Баркона микробная биомасса скорее уменьшалась, но возрастала ее активность, выражаемая в величине потоков азота через биомассу (служит функцией количества и активности микроорганизмов и отражает работу микроорганизмов в почве) (32). Меньший размер потоков азота в опыте 2 
2. Численность, содержание и активность биомассы микроорганизмов в дерново-подзолистой почве при внесении соломы и использовании биопрепарата Баркон $\left(M \pm t_{0,05} \times \mathrm{SEM}\right)$

\begin{tabular}{|c|c|c|c|c|c|c|c|c|}
\hline Вариант & $\begin{array}{l}\text { Аммонифициру- } \\
\text { ющие, млн КОЕ/г } \\
\text { почвы }\end{array}$ & $\begin{array}{l}\text { Амилолитиче- } \\
\text { ские, млн КОЕ/г } \\
\text { почвы }\end{array}$ & $\begin{array}{l}\text { Гумусразлагаю- } \\
\text { щие, млн КОЕ/г } \\
\text { почвы }\end{array}$ & \begin{tabular}{|l} 
Целлюлозоразлага- \\
ющие, тыс. КОЕ/г \\
почвы
\end{tabular} & $\begin{array}{l}\text { Микромицеты, } \\
\text { тыс. КОЕ/г почвы }\end{array}$ & $\mathrm{C}_{\text {б.м. }}, \mathrm{Mг} / \mathrm{кг}$ & $\mathrm{N}_{\text {б.м. }}, \mathrm{мг} / \mathrm{кг}$ & Поток N, мг/кг \\
\hline \multicolumn{9}{|c|}{ О п ы т 1 (л абор ат орны й, 2 мес) } \\
\hline Контроль & $3,4 \pm 0,2$ & $3,1 \pm 0,1$ & $1,4 \pm 0,1$ & \multirow{2}{*}{\multicolumn{2}{|c|}{0,95}} & $344 \pm 4$ & $55,3 \pm 12,2$ & $54,0 \pm 4,1$ \\
\hline Солома + почвенный & & & & & & & & \\
\hline инокулюм & $6,0 \pm 0,1$ & $8,2 \pm 0,4$ & $4,2 \pm 0,4$ & 15 & - & $576 \pm 56$ & $98,7 \pm 19,9$ & $181,0 \pm 7,2$ \\
\hline Солома + Баркон & $6,8 \pm 0,2$ & $7,8 \pm 0,8$ & $4,4 \pm 0,4$ & \multicolumn{2}{|l|}{15} & $344 \pm 52$ & $102,0 \pm 9,3$ & $25,0 \pm 3,4$ \\
\hline \multicolumn{9}{|c|}{ Оп ы т 2 (л а бор аторны й, 2 мес) } \\
\hline Контроль & $12,0 \pm 0,8$ & $8,7 \pm 0,6$ & $6,3 \pm 0,6$ & $15,8 \pm 2,1$ & $23,5 \pm 3,5$ & $571 \pm 60$ & $43,9 \pm 0$ & $87,0 \pm 6,5$ \\
\hline Солома, 0-3 см & $16,4 \pm 0,3$ & $14,0 \pm 1,4$ & $6,8 \pm 1,0$ & $65,8 \pm 8,1$ & $26,5 \pm 3,5$ & $697 \pm 52$ & $53,0 \pm 4,2$ & $112,0 \pm 4,6$ \\
\hline Солома, 9-12 см & $12,9 \pm 0,8$ & $14,1 \pm 1,1$ & $9,5 \pm 0,7$ & $61,8 \pm 14,0$ & $20,4 \pm 2,1$ & $807 \pm 39$ & $53,4 \pm 4,9$ & $87,0 \pm 2,3$ \\
\hline Солома + Баркон, 0-3 см & $14,3 \pm 0,5$ & $13,4 \pm 1,5$ & $8,6 \pm 1,0$ & $127,2 \pm 16,1$ & $30,4 \pm 3,7$ & $626 \pm 34$ & $45,9 \pm 2,7$ & $129,0 \pm 2,1$ \\
\hline Солома + Баркон, 9-12 см & $13,8 \pm 1,0$ & $13,8 \pm 1,6$ & $8,7 \pm 0,9$ & $98,9 \pm 14,0$ & $13,0 \pm 1,4$ & $603 \pm 72$ & $41,9 \pm 5,6$ & $99,0 \pm 9,6$ \\
\hline \multicolumn{9}{|c|}{ О п ы т 3 (п о л е в о й, 3 сут/17 сут) } \\
\hline Контроль, 0-5 см & $18,0 \pm 5,9 / 19,6 \pm 7,9$ & $9,2 \pm 2,8 / 9,2 \pm 4,5$ & $4,3 \pm 0,2 / 5,5 \pm 1,3$ & $8,0 \pm 2,8 / 10,4 \pm 2,3$ & $13,6 \pm 4,2 / 18,8 \pm 4,2$ & $562 \pm 1 / 410 \pm 12$ & $28,8 \pm 0 / 35,2 \pm 0$ & $253,0 \pm 2,3$ \\
\hline Контроль, $10-15$ см & $18,6 \pm 6,8 / 32,1 \pm 3,3$ & $9,7 \pm 2,0 / 9,5 \pm 4,6$ & $4,9 \pm 0,5 / 8,1 \pm 0,8$ & $6,7 \pm 0,5 / 8,5 \pm 0,8$ & $14,5 \pm 1,1 / 24,0 \pm 5,3$ & $498 \pm 25 / 460 \pm 61$ & $27,9 \pm 0 / 38,2 \pm 0$ & $262,0 \pm 13,8$ \\
\hline Солома, 0-5 см & $107,1 \pm 20,2 / 27,6 \pm 3,4$ & $67,8 \pm 16,7 / 20,3 \pm 8,4$ & $8,8 \pm 0,3 / 12,0 \pm 2,4$ & $7,3 \pm 2,4 / 10,3 \pm 3,4$ & $10,9 \pm 3,6 / 23,8 \pm 6,6$ & $694 \pm 48 / 597 \pm 118$ & $35,2 \pm 1,2 / 54,0 \pm 4,8$ & $513,0 \pm 5,9$ \\
\hline Солома, $10-15$ см & $59,3 \pm 0,7 / 46,4 \pm 0$ & $69,4 \pm 1,5 / 23,2 \pm 0$ & $9,8 \pm 0,4 / 14,5 \pm 0,8$ & $4,7 \pm 1,3 / 3,9 \pm 0,8$ & $12,5 \pm 3,3 / 23,2 \pm 2,7$ & $557 \pm 60 / 640 \pm 6$ & $24,6 \pm 6,1 / 60,6 \pm 11$ & $821,0 \pm 7,8$ \\
\hline Солома + Баркон, 0-5 см & $70,6 \pm 2,1 / 46,8 \pm 12,1$ & $54,1 \pm 3,5 / 21,1 \pm 5,6$ & $11,7 \pm 0,5 / 12,2 \pm 1,7$ & $11,3 \pm 0,8 / 8,2 \pm 1,3$ & $16,5 \pm 3,2 / 27,6 \pm 2,3$ & $525 \pm 61 / 694 \pm 14$ & $27,2 \pm 0 / 54,0 \pm 4,8$ & $758,0 \pm 4,9$ \\
\hline Солома + Баркон, 10-15 cм & $57,3 \pm 3,5 / 61,2 \pm 20,2$ & $44,0 \pm 13,7 / 28,1 \pm 9,3$ & $11,3 \pm 0,6 / 11,90$ & $9,7 \pm 1,4 / 7,0 \pm 2,3$ & $14,5 \pm 4,7 / 29,3 \pm 0$ & $442 \pm 86 / 710 \pm 10$ & $25,9 \pm 9,3 / 59,7 \pm 9,5$ & $858,0 \pm 13,1$ \\
\hline
\end{tabular}


3. Распределение бактерий в дерново-подзолистой почве по мажорным таксонам (\% от общего числа операционных таксономических единиц, ОТЕ) при внесении соломы и использовании биопрепарата Баркон $\left(M \pm t_{0,05} \times \mathrm{SEM}\right)$

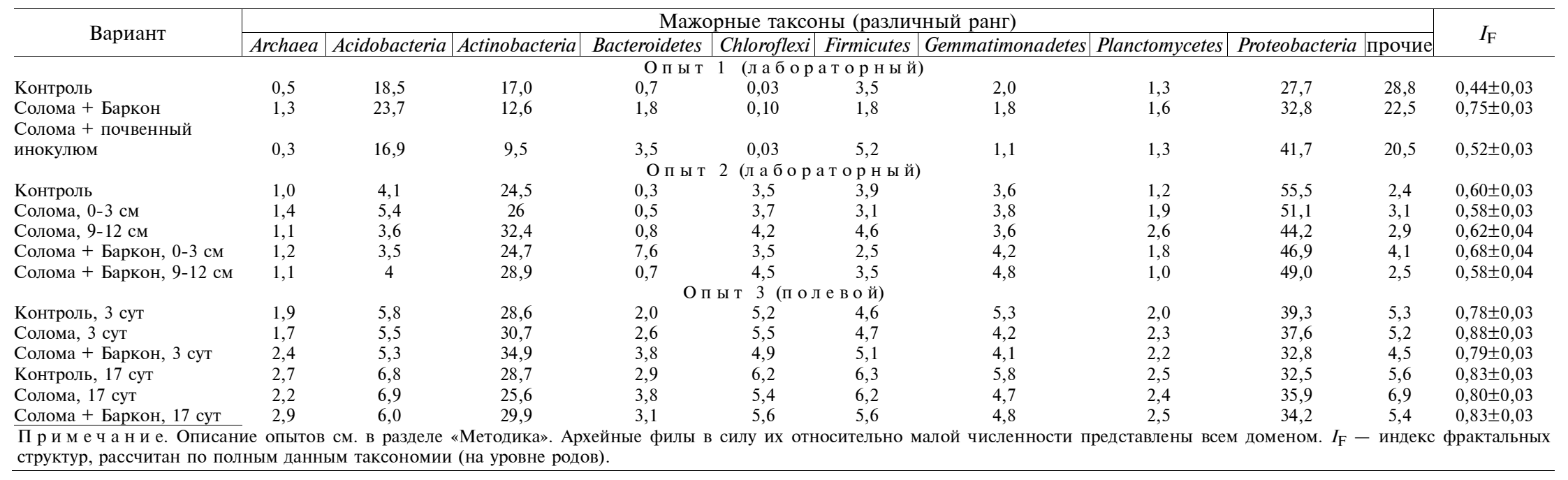


был вызван слабым разложением соломы ржи и низким содержанием в ней азота, поскольку для разложения соломы в окультуренной высокогумусной почве бактериям требуется больше доступного азота (43).

Наличие взаимосвязи между структурой микробного сообщества и агрономическими свойствами почвы при разложении соломы следует из двух дендрограмм (39), полученных для опыта 1, из которых первая была построена по микробиологическим (численность, биомасса, активность) и агрохимическим показателям, а вторая - по таксономическому составу микробного сообщества почв. Дендрограммы имели идентичную структуру кластеров (данные не представлены). Полученные результаты показали, что обработка биопрепаратом Баркон имела сильное влияние на структуру микробного сообщества, поскольку этот вариант не вошел в один кластер с соломой, разлагавшейся почвенным инокулюмом.

Основную массу бактериального сообщества исследованных почв составляли представители фил Actinobacteria и Proteobacteria, сушественное количество микроорганизмов принадлежало филам Acidobacteria, Chloroflexi, Firmicutes, Gemmatimonadetes (табл. 3).

Микробный препарат Баркон содержал значительное число видов микроорганизмов (рис. 1), не совпадающее с почвенным микробиомом. Например, в Барконе было почти на порядок меныше типичных почвенных обитателей - Acidobacteria. В то же время в биопрепарате по сравнению с почвой была выше доля Bacilli, Sphingobacteria и Gemmatimonadetes. Биопрепарат Баркон предназначен для разложения целлюлозосодержащих отходов, поэтому в его бактериальном сообществе много актиномицетов (Cellulomonas, Corynebacterium, Micrococcaceae), разлагающих целлюлозу и другие труднодоступные органические соединения, причем различия с почвой составляли как минимум порядок.

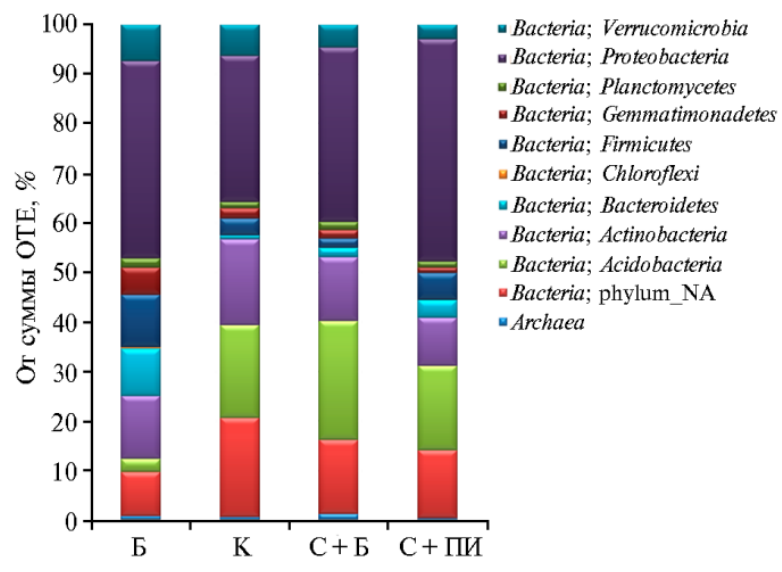

Рис. 1. Состав бактериального микробного сообщества биопрепарата Баркон и дерново-подзолистой почвы при внесении пшеничной соломы и использовании Баркона в опыте 1: Б - Баркон, К - контроль (почва), С + Б солома + Баркон, С + ПИ - солома + почвенный инокулюм.

При анализе бактериального сообщества дерново-подзолистых почв было выявлено, что микробиомы в трех опытах существенно различались между собой (см. табл. 3). Все три почвы сформировали отдельные кластеры, то есть наибольшее влияние на структуру микробного сообщества оказывал фактор почв (см. табл. 3). Этот вывод отличается от утверждения о том, что главным фактором в формировании микробного сообщества, разлагающего солому, служат климатические условия, а не тип почвы (47). Однако внесение соломы, применение биопрепарата, срок анализа и глубина заделки также оказывали значительное влияние на состав микробного сообщества. Например, при использовании Баркона по сравнению с почвенным инокулюмом

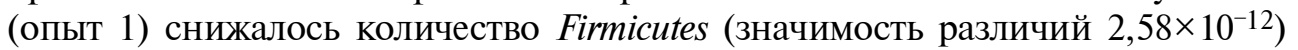
(41), Bacteroidetes $\left(6,34 \times 10^{-5}\right)$, Proteobacteria $\left(1,26 \times 10^{-12}\right)$ и возрастала доля Acidobacteria $\left(8,07 \times 10^{-11}\right)$, Actinobacteria $\left(1,2 \times 10^{-4}\right)$ и архей $\left(7,8 \times 10^{-4}\right)$. 
При анализе полученных данных особое внимание уделяли нескольким наиболее важным таксонам, так как значительная часть микроорганизмов не принимала прямого участия в разложении соломы. Следует отметить, что для каждой почвы был характерен свой, не всегда совпадающий набор семейств в каждом таксоне. Так, чувствительным индикатором для величины рН почв может быть не только представленность класса Acidobacteria, но и его состав (48). В наших опытах установлено, что при близком содержании $\mathrm{C}_{\text {орг. }}$ в более кислых почвах в этом таксоне преобладали Acidobacteria 1-й и 2-й групп (соответственно 60 и $18 \%$ ), в почвах с величиной $\mathrm{pH}$, близкой к нейтральной, преобладала 6-я группа - 30 \% (для опыта 1 - 1-3 \%), а 1-ю и 2-ю группы не идентифицировали. Acidobacteria 6-й группы положительно отзывались на внесение соломы на кислой почве (наблюдался рост с 1 до $3 \%$ ).

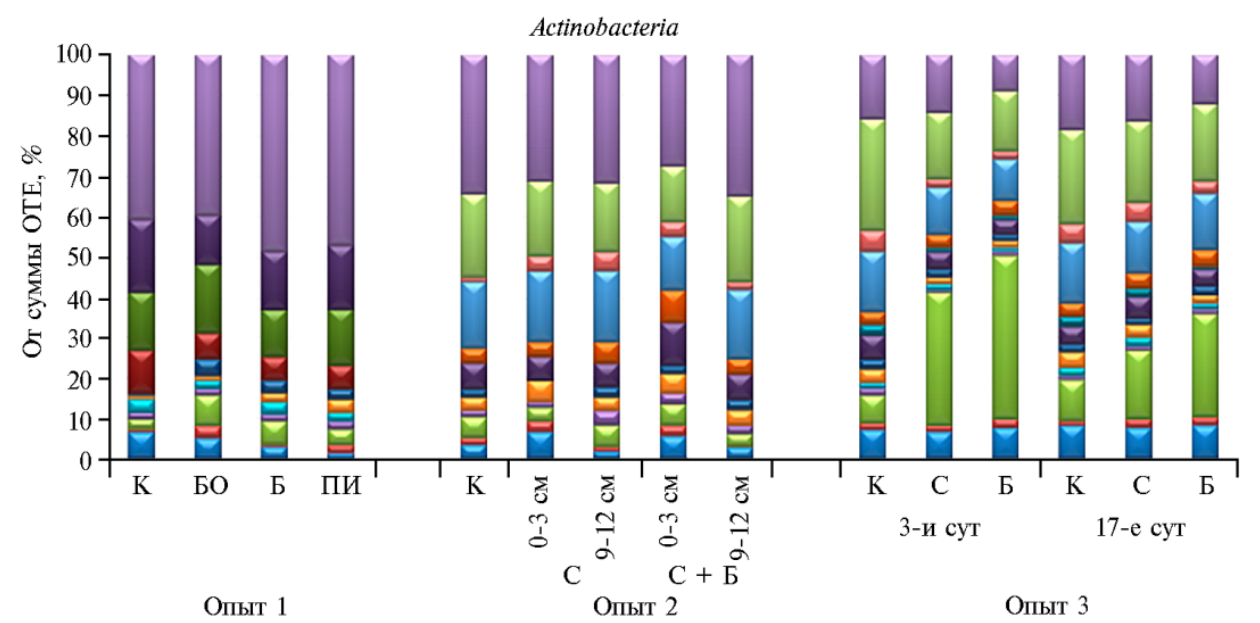

$\square_{1} \square_{2} \square_{3} \square_{4} \square_{5} \square_{6} \quad 7 \quad \square 8 \quad \square_{9} \quad \square_{10} \square_{11} \square_{12} \square_{13} \square_{14} \square_{15} \square_{16}$

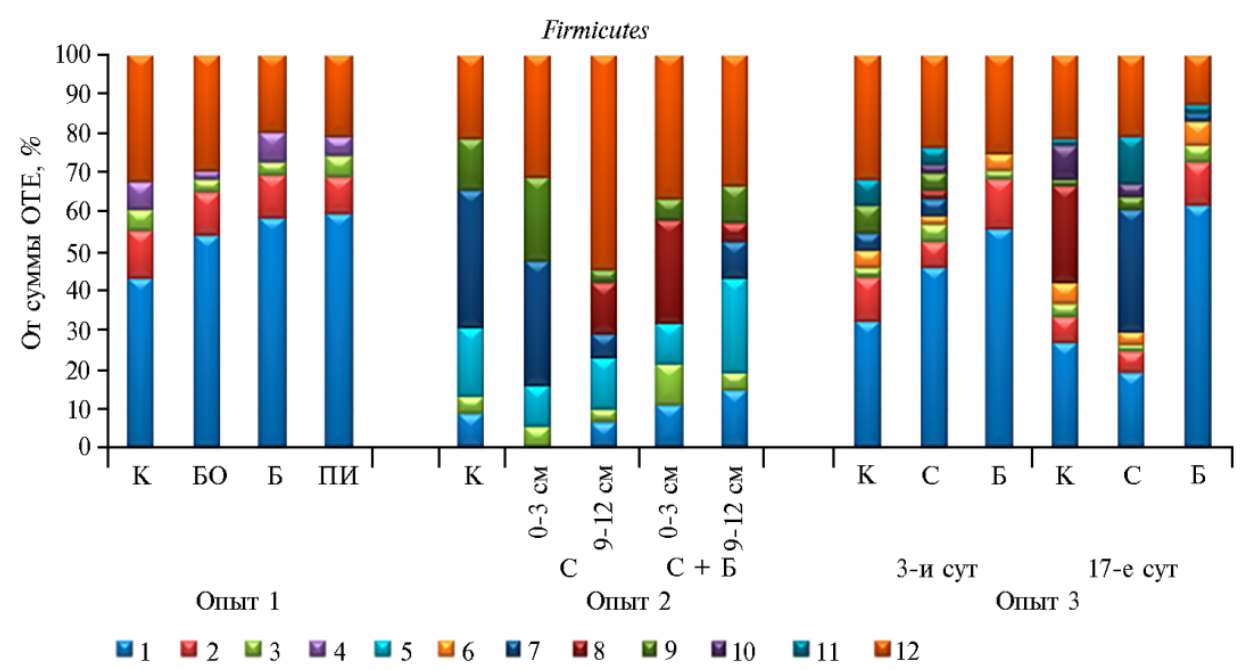

Рис. 2. Состав отдельных фил на уровне семейств в опытах (доля от суммы операционных таксономических единиц - ОТЕ) при внесении в дерново-подзолистую почву соломы и использовании биопрепарата Баркон: $\mathrm{K}$ - контроль, БО - без обработки, Б - Баркон, С солома, ПИ - почвенный инокулюм. Семейства Actinobacteria: 1 - Intrasporangiaceae, 2 Microbacteriaceae, 3 - Micrococcaceae, 4 - Micromonosporaceae, 5 - Mycobacteriaceae, 6 - Pseudonocardiaceae, 7 - Streptomycetaceae, 8 - Thermomonosporaceae, 9 - Conexibacteraceae, 10 Solirubrobacteraceae, 11 - Geodermatophilaceae, 12 - Nocardioidaceae, 13 - Gaiellaceae, 14 - 
Patulibacteraceae, 15 - Solirubrobacterales, 16 - прочие. Семейства Firmicutes: 1 - Bacillaceae, 2 Paenibacillaceae, 3 - Clostridiaceae, 4 - Planococcaceae, 5 - Carnobacteriaceae, 6 - Alicyclobacillaceae, 7 - Staphylococcaceae, 8 - Lactobacillaceae, 9 - Streptococcaceae, 10 - Veillonellaceae, 11 [Tissierellaceae], 12 - прочие. Описание опытов см. в разделе «Методика».

Актиномицеты играют существенную роль в минерализации трудноразлагаемых субстратов, в том числе соломы $(2,17,49)$. Индикаторной группой на внесение соломы для дерново-подзолистой почвы во всех опытах служило семейство Micrococcaceae. Его представители входят в состав биопрепарата Баркон (23). Наблюдаемое в опыте 3 на 3-и сут существенное возрастание доли Micrococcaceae от всех актинобактерий в вариантах с соломой (рис. 2) сохранялось на 17-е сут, хотя значительно падало $(10,17$ и $26 \%$ соответственно для контроля, соломы и соломы + Баркон). Повышенная доля бактерий этого семейства отмечалась и в опыте 1 на 61-е сут (см. рис. 2). Спорообразующие микроорганизмы из филы Firmicutes также могут принимать участие в разложении свежего органического вещества. Биопрепарат оказывал на ее состав значительное действие, уменьшая количество родов (см. рис. 2). Наибольшее влияние наблюдали в первые дни после внесения соломы и биопрепарата (опыт 3), но оно сохранялось и для более поздних сроков: в опыте 1 число родов в контроле и соломе с почвенным инокулюмом составляло 17, в варианте с Барконом - 10. В опыте 2 с богатой органическим веществом почвой влияние Баркона проявилось только при его заделке в нижний слой: число родов в этой филе для соломы и соломы с Барконом составляло соответственно 15 и 11.

Соотношение грамположительных и грамотрицательных бактерий характеризует олиготрофность почвенных процессов. Известно, что грамотрицательные бактерии требуют более богатого субстрата (свежего органического вещества). При разложении соломы увеличивается их количество, особенно Alphaproteobacteria и Gammaproteobacteria (46, 48). В наших опытах, за исключением первого, не было обнаружено увеличения грамотрицательных бактерий в зависимости от внесения соломы. Даже в опыте 3 при внесении легкоразлагаемой соломы овса мы не обнаружили увеличения доли грамотрицательных бактерий. Причина может быть как в различиях с методами, используемыми другими исследователями (метод жирных кислот), так и в высокой доле некультивируемых микроорганизмов.

Для оценки влияния изучаемых факторов на разнообразие микробных сообществ использовали индекс Шеннона. В опыте 2 при внесении соломы он ожидаемо возрастал относительно контроля. Баркон несколько снижал разнообразие микробного сообщества почвы при разложении соломы в нижнем слое (контроль - 5,04; солома в слое 0-3 и 9-12 см - соответственно 5,47 и 5,57, Баркон - 6,22 и 5,17). В опытах 1 и 3 существенных различий по индексу Шеннона между вариантами не наблюдали. Коэффициент сходства Серенсена-Чекановского показал, что таксономический состав микробного сообщества биопрепарата (для опыта 1) значительно различался с любыми почвенными вариантами $(0,54-0,59$ против 0,72-0,75). Для опыта 2 состав микробного сообщества, разлагающего солому в верхнем слое, имел наибольшее сходство с контролем $(0,82)$, тогда как обработка Барконом и разложение в нижнем слое снижали коэффициент сходства до 0,67-0,70. Следовательно, при обработке биопрепаратом наибольшие различия по составу микробных сообществ по обоим коэффициентам были при заделке соломы в нижний слой.

При анализе данных таксономического состава по методу главных компонент были показаны существенные различия между почвой и биопрепаратом в опыте 1 (рис. 3, А). Значительными оказались и изменения в 
структуре микробного сообщества, разлагающего солому, при внесении Баркона. Различия между повторностями были сравнимы с различиями по вариантам (см. рис. 3, В), хотя и на низком уровне (не более $9 \%$ ), особенно для варианта с соломой на 17-е сут. Вероятно, это связано с наличием вокруг кусочков разлагающейся соломы дейтритосферы $(46,50,51)$. Тем не менее влияние Баркона на 3-е сут было достаточно четким. Для опыта 2 показано значительное различие микробных сообществ в разных слоях (см. рис. 3, Б).

A

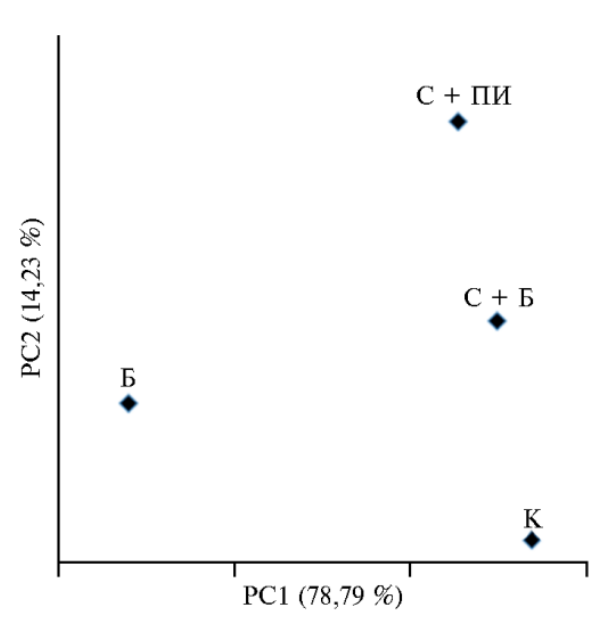

B

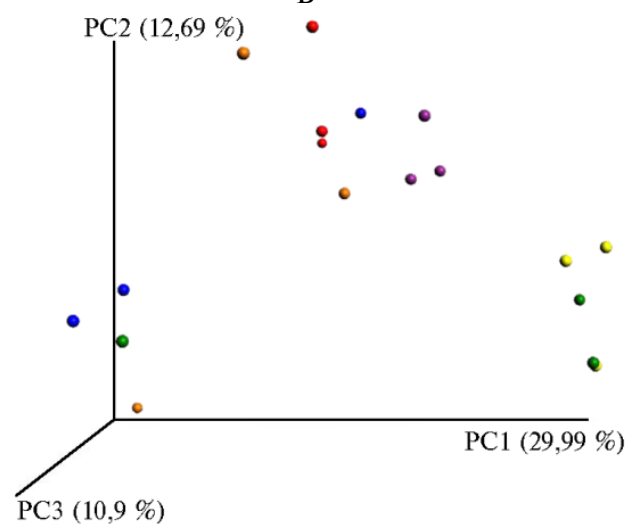

Б

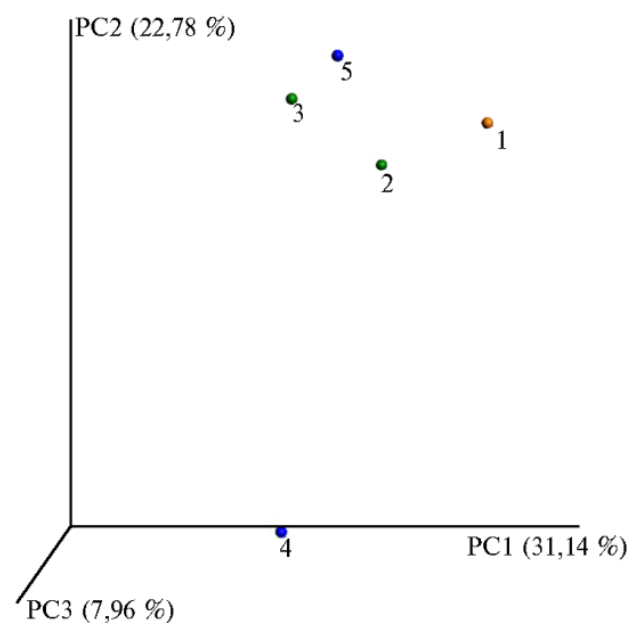

Рис. 3. Анализ различий между пробами методом главных компонент.

А (опыт 1): К - контроль, Б - Баркон, С + Б - солома + Баркон, С + ПИ солома + почвенный инокулюм.

Б (опыт 2): 1 - контроль, 2 - солома в слое 0-3 см, 3 - солома в слое 9-12 см, 4 - солома + Баркон в слое $0-3$ см, 5 солома + Баркон в слое 9-12 см.

В (опыт 3): цветные обозначения $\square \square \square \square-$ соответственно контроль на 17-е сут, контроль на 3-и сут, солома на 17-е сут, солома на 3-и сут, солома + Баркон на 17-е сут, солома + Баркон на 3-и сут. Описание опытов см. в разделе «Методика».

Фрактальный анализ молекулярно-генетических данных, представленных в форме фрактального портрета $(23,37,38)$, сводился к под счету числа первичных фрактальных групп (ПФГ). При поиске ПФГ на портрете последовательно анализируется расположение фрактальных триплетов, в которые входят точки, отличающиеся целыми частями логарифма частот встречаемости и расположенные на одной прямой. Абсолютно точное расположение трех точек на одной прямой - исключительная ситуация. Поэтому все найденные ПФГ характеризуются не только таксономическими параметрами групп ОТЕ, но и погрешностью $(h)$ расположения трех точек на одной прямой. Мы предполагаем, что сообщество микроорганизмов, в котором присутствует большее число ПФГ, обладает большей согласованностью и эффективностью совместной преобразовательной деятельности микроорганизмов.

В качестве показателя эффективности совместной преобразовательной деятельности сообщества микроорганизмов предлагается вычис- 
лять индекс фрактальных структур микробного сообщества по следующей формуле:

$$
I_{F}=N_{П Ф Г}(h) / N_{M},
$$

где $N_{П Ф Г}(h)$ - число разных групп ОТЕ (оперативная таксономическая единица) в первичных фрактальных группах, выделенных на фрактальном портрете микробного сообщества для $\ln (h)<=-5 . .-3 ; N_{M}-$ общее число групп ОТЕ, объединяющие индивидуальные ОТЕ с близкими частотами встречаемости.

Для успешной утилизации соломы микроорганизмы формируют биосистемы с фрактальной организацией сетевых структур, в которых распределены преобразовательные биохимические роли микроорганизмов и согласуется порядок совместных преобразовательных действий. При неудачной сборке деструктивной биосистемы (например, при отсутствии необходимых микроорганизмов) эффективность преобразований растительных субстратов в почве оказывается низкой, что приводит к снижению индекса фрактальных структур микробного сообщества. Например, в опыте 3 с неинокулированной соломой на 17-е сут индекс фрактальных структур был меньше $\left(I_{F}=0,80\right)$, чем в этом же опыте в варианте с соломой и Барконом на 17 -е сутки $\left(I_{F}=0,83\right)$ (табл. 3). Это означает, что микроорганизмы препарата встраиваются в почвенные деструктивные биосистемы при отсутствии в ней необходимых микроорганизмов.

Для формирования деструктивных биосистем микроорганизмам необходимо некоторое время, чтобы настроится на совместную работу, распределить трансформирующие роли и установить порядок преобразовательных действий. Поэтому в опыте 3 на 3-и сут почвенное микробное сообщество (с внесением соломы и Барконом) еще полностью не настроилось $\left(I_{F}=0,79\right)$, а настроилось на 17 -е сут $\left(I_{F}=0,83\right)$. Если сравнивать варианты опыта 2, различающиеся глубиной внесения соломы, инокулированной Барконом, то эффективность деструктивной микробной биосистемы была больше при внесении соломы в верхние (см. табл. $3 ; I_{F}=0,68$ ), чем в нижние слои почвы $\left(I_{F}=0,58\right)$. Вероятное объяснение заключается в том, обстоятельством, что применение Баркона достигает лучших результатов по формированию деструктивных микробных биосистем, если в составе биосистем превалируют аэробные микроорганизмы, которые могут достаточном количестве получать энергию для биохимических преобразований растительных субстратов посредством окисления органических веществ.

В опыте 1 индексы фрактальных структур (см. табл. 3) в контроле и при инокуляции соломы почвенной вытяжкой были меньше $\left(I_{F}=0,44\right.$ и 0,52), чем при использовании соломы, инокулированной Барконом $\left(I_{F}=0,75\right)$. То есть микроорганизмы в процессе приготовления этого биопрепарата образовали сетевые структуры, готовые к совместной преобразовательной биохимической деятельности.

Таким образом, обработка биопрепаратом Баркон способствует формированию микробных деструктивных сообществ с наибольшей эффективностью преобразования соломы и перевода ее в лабильные органические соединения, а затем и в гумусовые вещества почвы. При разложении соломы в почве по сравнению с незаделанной наблюдается некоторое ослабление действия Баркона на образование гумификационной трофической цепи, о чем свидетельствует отсутствие прироста лабильных гумусовых веществ в соответствующих вариантах. Наибольшее влияние на состав микробных сообществ, ведущих разложение соломы, оказывает вид почвы, меньшее - ее химические, физические, биохимические характеристики. 
Наличие взаимосвязи комплекса почвенно-микробиологических данных (численность и биомасса микроорганизмов, дыхание) с таксономическим составом микробоценоза подтверждает высокую реакцию состава микробного сообщества на различные воздействия при сохранении корового компонента микробиома, характерного для конкретной почвы. Впервые по микробным профилям почвенных образцов показано, что в вариантах с инокуляцией соломы биопрепаратом Баркон возрастает доля семейства Micrococcaceae, представители которого служат одними из составляющих микробных компонентов этого биопрепарата. Установлено, что минорные группы микроорганизмов участвуют наравне с мажорными в образовании сетевых фрактальных структур. Показано, что микробиологический препарат повышает индекс фрактальных структур микробного сообщества, особенно в верхних слоях пахотного горизонта, то есть создает условия для эффективной утилизации соломы в почве, увеличивая скорость переработки соломы в гумусовые соединения.

Авторы благодарят А.Ю. Колодяэнного, Ю.П. Москалевскую и Н.В. Патыку (Украина) за участие в выполнении опыта 2.

\footnotetext{
1 ФГБНУ Всероссийский НИИ сельскохозяйственной микробиологии,

196608 Россия, г. Санкт-Петербург-Пушкин, ш. Подбельского, 3, e-mail: falenki@hotmail.com $\square$, biologartillerist@gmail.com, nik4@newmail.ru, osviridova65@yandex.ru, lisina-to@yandex.ru, eeandr@gmail.com;

2 ФГБОУ ВО Санкт-Петербургский государственный университет,

199034 Россия, г. Санкт-Петербург, Университетская наб., 7/9;

ЗФГБНУ Почвенный институт им. В.В. Докучаева, 397463 Россия, г. Москва, Пыжевский пер., 7, стр. 2
}

Поступила в редакцию 8 октября 2018 года

Sel’skokhozyaistvennaya biologiya [Agricultural Biology], 2019, V. 54, № 1, pp. 47-64

\title{
TAXONOMIC COMPOSITION AND ORGANIZATION \\ OF THE MICROBIAL COMMUNITY OF SODDY-PODZOLIC SOILS AFTER APPLICATION STRAW OF CEREAL CROPS AND USING OF THE BARKON BIOPREPARATION
}

\author{
O.V. Orlova', E.L. Chirak' ${ }^{1}$, N.I. Vorob'ev' ${ }^{1}$, O.V. Sviridova ${ }^{1}$, T.O. Lisina', \\ E.E. Andronov1, 2, 3
}

\footnotetext{
${ }^{1}$ All-Russian Research Institute for Agricultural Microbiology, 3, sh. Podbel'skogo, St. Petersburg, 196608 Russia, e-mail falenki@hotmail.com ( $₫$ corresponding author), biologartillerist@gmail.com, nik4@newmail.ru, osviridova65@yandex.ru, lisina-to@yandex.ru, eeandr@gmail.com;

${ }^{2}$ Saint Petersburg State University, 7/9, Universitetskaya nab., St. Petersburg, 199034 Russia;

${ }^{3}$ Dokuchaev Soil Science Institute, 7/2, Pyzhyovskiy per., Moscow, 397463 Russia

ORCID:

Orlova O.V. orcid.org/0000-0002-2154-503X

Chirak E.L. orcid.org/0000-0001-9167-5000

Sviridova O.V. orcid.org/0000-00015722-5620

Lisina T.O. orcid.org/0000-0003-1268-4166

Vorob'ev N.I. orcid.org/0000-0001-8300-2287

Andronov E.E. orcid.org/0000-0002-5204-262X

The authors declare no conflict of interests

Acknowledgements:

The authors thank A.Yu. Kolodyazhny, Yu.P. Moskalevskaya and N.V. Patyka (Ukraine) for their assistance in the experiment 2.

Experiments have been carried out on the equipment of ARRIAM Center for genomic technologies, proteomics and cell biotechnology.

Supported financially by Russian Science Foundation (grant № 18-16-00073)

Received October 8, 2018

doi: 10.15389 /agrobiology.2019.1.47eng
}

\section{Abstract}

The modern concept of the reproduction of soil organic matter (SOM) requires the sequestration of the carbon of plant residues in the soil by the formation of stable organic compounds. In this regard. the role of microbial preparations, accelerating the decomposition of straw are important. Learning the taxonomic structure of the microbial community in these processes is of great im- 
portance and not well understood. Microbial communities of arable soddy-podzolic soils decomposing straw of grain crops were studied in field and laboratory experiments. Straw (rye, wheat and oat) were crushed and inoculated with the Barkon preparation (complex association of microorganisms developed at the FGBNU ARRIAM). The functioning of the microbial community was assessed by the number and activity of microorganisms, the agrochemical properties of the soil. The composition of bacterial community of soils was determined by high-performance sequencing of 16s rRNA gene libraries. The rate of decomposition of straw was controlled by the ratio $\mathrm{C}: \mathrm{N}$ in it: rye straw $<$ wheat $<$ oat. Barkon increased rate of decomposition of straw by 18-42\% compared to soil microflora by 3 months of composting. Biopreparation is more effective when straw is incorporation in the $0-5 \mathrm{~cm}$ layer than by $9-12 \mathrm{~cm}$. The effect of the Barkon on the number, biomass of microorganisms, and their respiration was not noticeable as compared with the growth of these parameters when introducing straw. The absence of an increase in carbon dioxide emissions with an increase in the rate of straw decomposition when Barkon is introduced, indicates an intensification of the processes of carbon sequestration in soil. The treatment with a biological preparation promotes the formation of microbial destructive communities with the highest efficiency of straw conversion and its conversion into labile organic compounds, and then into soil humus substances. Therefore, the use of Barkon, compared to the uninoculated straw, increased the content of total carbons in the soil by 4.8 to $8.4 \%$. All studied factors (soil, straw, biological preparation, depth and time of decomposition) influence on the composition of microbial communities leading decomposition, the most significant of which is the type of soil. This confirms the high response of the composition of the microbial community to various factors while maintaining the crustal component of the microbiome characteristic of this soil. In the more acid soddy-podzolic soils, at the same humus content, in the taxon Acidobacteria, group 1 and group 2 prevailed, while in the soils with a neutral $\mathrm{pH}$, group 6 predominated. The indicator of straw application for sod-podzolic soil in all experiments is the increase of Actinobacteria from the family Micrococcaceae, particularly in variants with straw inoculation with Barkon, since Micrococcaceae is one of the microbial components of this biopreparation. Detected the influence of adding straw and application of the Barkon on the taxonomic composition of the bacterial community and the configuration of the destructive biosystem of soil microorganisms tuned for humification of plant residues. The decomposition of straw in the soil, as compared to that which was not planted, showed some weakening of Barkon's effect on the formation of the humification trophic chain, as evidenced by the lack of growth of labile humic substances in the respective variants. Based on the extended taxonomic data on the composition of the soil microbial community, it was found that minor groups of microorganisms participate equally with major groups, forming network fractal structures.

Keywords: microbial community, straw, a microbiological preparations, Barkon, the index of fractal structures.

\section{R E F E R E N C ES}

1. Fageria N.K. Role of soil organic matter in maintaining sustainability of cropping systems. Commun. Soil Sci. Plant, 2012, 43(16): 2063-2113 (doi: 10.1080/00103624.2012.697234).

2. Ispol'zovanie solomy kak organicheskogo udobreniya /Pod redaktsiei E.N. Mishustina [Using straw as organic fertilizer]. Moscow, 1980 (in Russ.).

3. Mahmoodabadi M., Heydarpour E. Sequestration of organic carbon influenced by the application of straw residue and farmyard manure in two different soils. International Agrophysics, 2014, 28(2): 169-176 (doi: 10.2478/intag-2014-0005).

4. Golubev I.G., Shvanskaya I.A., Konovalenko L.Yu., Lopatnikov M.V. Retsikling otkhodov v APK: spravochnik [Waste recycling in agricultural sector: a handbook]. Moscow, 2011 (in Russ.).

5. Surekha K., Reddy K.P.C., Kumari A. P.P., Sta Cruz P.C. Effect of straw on yield components of rice (Oryza sativa L.) under rice-rice cropping system. J. Agron. Crop Sci., 2006, 192(2): 92101 (doi: 10.1111/j.1439-037X.2006.00192.x).

6. Rusakova I.V., Vorob'ev N.I. Dostizheniya nauki i tekhniki APK, 2011, 08: 25-28 (in Russ.).

7. Zhang P., Wei T., Jia Z., Han Q., Ren X., Li Y. Effects of straw incorporation on soil organic matter and soil water-stable aggregates content in semiarid regions of Northwest China. PloS ONE, 2014, 9(3): e92839 (doi: 10.1371/journal.pone.0092839).

8. Li P., Zhang D. D., Wang X. J., Wang X., Cui Z. Survival and performance of two cellulosedegrading microbial systems inoculated into wheat straw-amended soil. J. Microbiol. Biotechn., 2012, 22(1): 126-132 (doi: 10.4014/jmb.1102.02021).

9. Shershneva O.M., Tarasov S.A. Vestnik Kurskoi gosudarstvennoi sel'skokhozyaistvennoi akademii, 2014, 6: 41-45 (in Russ.).

10. Pfender W.F., Fieland V.P., Ganio L.M., Seidler R.J. Microbial community structure and activity in wheat straw after inoculation with biological control organisms. Applied Soil Ecology, 1996, 3(1): 69-78 (doi: 10.1016/0929-1393(95)00068-2). 
11. Semenov V.M., Ivannikova L.A., Tulina A.S. Agrokhimiya, 2009, 10: 77-96 (in Russ.).

12. Hatfield J.L., Walthall C.L. Soil biological fertility: Foundation for the next revolution in agriculture? Commun. Soil Sci. Plant., 2015, 46(6): 753-762 (doi: 10.1080/00103624.2015.1005227).

13. Nannipieri P., Ascher J., Ceccherini M.T., Landi L., Pietramellara G., Renella G. Microbial diversity and soil functions. Eur. J. Soil Sci., 2003, 54(4): 655-670 (doi: 10.1046/j.13510754.2003.0556.x).

14. McGuire K.L., Treseder K.K. Microbial communities and their relevance for ecosystem models: decomposition as a case study. Soil Biology and Biochemistry, 2010, 42(4): 529-535 (doi: 10.1016/j.soilbio.2009.11.016).

15. Young I.M., Crawford J.W. Interactions and self-organization in the soil-microbe complex. Science, 2004, 304(5677): 1634-1637 (doi: 10.1126/science.1097394).

16. Crawford J.W., Deacon L., Grinev D., Harris J.A., Ritz K., Singh B.K., Young I. Microbial diversity affects self-organization of the soil-microbe system with consequences for function. Journal of the Royal Society Interface, 2012, 9(71): 1302-1310 (doi: 10.1098/rsif.2011.0679).

17. Marschner P., Kandeler, E., Marschner, B. Structure and function of the soil microbial community in a long-term fertilizer experiment. Soil Biology and Biochemistry, 2003, 35(3): 453-461 (doi: 10.1016/S0038-0717(02)00297-3).

18. Wickings K., Grandy S., Reed S., Johnson N. The origin of litter chemical complexity during decomposition. Ecology Letters, 2012, 15(10): 1180-1188 (doi: 10.1111/j.1461-0248.2012.01837.x).

19. Sonnleitner R., Lorbeer E., Schinner F. Effects of straw, vegetable oil and whey on physical and microbiological properties of a chernozem. Applied Soil Ecology, 2003, 22(3): 195-204 (doi: 10.1016/S0929-1393(02)00159-2).

20. Tenney F.G., Waksman S.A. Composition of natural organic materials and their decomposition in the soil: IV. The nature and rapidity of decomposition of the various organic complexes in different plant materials, under aerobic conditions. Soil Sci., 1929, 28(1): 55-84.

21. Tikhonovich I.A., Kozhemyakov A.P., Chebotar' V.K., Kruglov Yu.V., Kandybin N.V., Laptev G.Yu. Biopreparaty $v$ sel'skom khozyaistve (Metodologiya i praktika primeneniya mikroorganizmov $v$ rastenievodstve $i$ kormoproizvodstve) [Biological products in agriculture (Methodology and practice of using microorganisms in crop production and feed production)]. Moscow, 2005 (in Russ.).

22. Biktasheva L.R., Belonogova N.V., Selivanovskaya S.Yu., Galitskaya P.Yu. Uchebnye zapiski Kazanskogo universiteta. Seriya estestvennye nauki, 2016, 158(4): 493-506 (in Russ.).

23. Sviridova O.V., Vorobyov N.I., Provorov N.A., Orlova O.V., Rusakova I.V., Andronov E.E., Pishchik V.N., Popov A.A., Kruglov Yu.V. The alignment of soil's conditions for plant's development during microbial destruction of plant's residues by microbial preparations. Agricultural Biology, 2016, 51(5): 664-672 (doi: 10.15389/agrobiology.2016.5.664eng) (in Engl.).

24. Sviridova O.V., Mikhaleva L.V., Vorob'ev N.I., Kochetkov V.V. Mikologiya i fitopatologiya, 2001, 35(6): 38-47 (in Russ.).

25. Orlova O.V., Andronov E.E., Vorobyov N.I., Kolodyazhnii A.Yu., Moskalevskaya Yu.P., Patyka N.V., Sviridova O.V. Composition and functioning of microbial communities in the decomposition of straw cereals in sod podzolic soil. Agricultural Biology, 2015, 50(3): 305-314 (doi: 10.15389/agrobiology.2015.3.305eng) (in Engl.).

26. Agrokhimicheskie metody issledovaniya pochv/Pod redaktsiei A.V. Sokolova [Agrochemical methods of soil research. A.V. Sokolov (ed.)]. Moscow, 1975 (in Russ.).

27. Spravochnik po analizu organicheskikh udobrenii /Pod redaktsiei A.I. Es'kova [Handbook of organic fertilizer analysis. A.I. Es'kov (ed.)]. Moscow, 2000 (in Russ.).

28. Safonov A.P. V knige: Gumus $i$ azot $v$ zemledelii nechernozemnoi zony RSFSR [Humus and nitrogen in agriculture non-chernozem zone of the RSFSR]. Leningrad, 1987: 14-16 (in Russ.).

29. Shul'ts E., Kershens M. Pochvovedenie, 1998, 7: 890-894 (in Russ.).

30. Panikov N.S., Gorbenko A.Yu., Svetlov S.V. Sposob opredeleniya summarnogo soderzhaniya vodorastvorimykh organicheskikh veshchestv $v$ pochve. Patent № 1318909 (SSSR) MKP G 01 N 33/24. MGU im. M.V. Lomonosova (SSSR). № 3949440/30-15. Zayavl. 06.09.85. Opubl. 23.06.87. Byul. № 23 [The method of determining the total content of water-soluble organic matter in the soil. Patent number 1318909 (USSR) MKP G 01 N 33/24. Moscow State University M.V. Lomonosov (USSR). No. 3949440/30-15. Claims 09/06/85. Publ. 06/23/87. Bul. No. 23] (in Russ.).

31. West A.W., Sparling G.P. Modification to the substrate-induced respiration method to permit measurement of microbial biomass in soils of different water contents. J. Microbiol. Meth., 1986, 5(3-4): 177-189 (doi: 10.1016/0167-7012(86)90012-6).

32. Blagodatskii S.A., Blagodatskaya E.V., Gorbenko A.Yu., Panikov N.S. Pochvovedenie, 1987, 4: 64-72 (in Russ.).

33. Osnovnye mikrobiologicheskie $i$ biokhimicheskie metody issledovaniya pochv: Metodicheskie ukazaniya [Main microbiological and biochemical methods of soil research: Methodical instructions]. Leningrad, 1987 (in Russ.).

34. Andronov E.E., Pinaev A.G., Pershina E.V., Chizhevskaya E.P. Nauchno-metodicheskie rek- 
omendatsii po vydeleniyu vysokoochishchennykh preparatov DNK iz ob"ektov okruzhayushchei sredy. Metodicheskie ukazaniya [Scientific and methodological recommendations on the isolation of highly purified DNA preparations from environmental objects]. St. Petersburg, 2011 (in Russ.).

35. Bates S.T.D., Berg-Lyons J.G., Caporaso W.A., Walters A. W., Knight R., Fierer N. Examining the global distribution of dominant archaeal populations in soil. The ISME Journal, 2010, 5: 908-917 (doi: 10.1038/ismej.2010.171).

36. Caporaso J.G., Bittinger K., Bushman F.D., DeSantis T.Z., Andersen G.L., Knight R. PyNAST: a flexible tool for aligning sequences to a template alignment. Bioinformatics, 2010, 26(2): 266-267 (doi: 10.1093/bioinformatics/btp636).

37. Vorob'ev N.I., Sviridova O.V., Patyka N.V., Dumova V.A., Mazirov M.A., Kruglov Yu.V. Materialy Mezhdunarodnoi konferentsii «Biodiagnostika v ekologicheskoi otsenke pochv $i$ sopredel'nykh sred» [Proc. Int. Conf. «Biodiagnostics in the environmental assessment of soils and adjacent environments»]. Moscow, 2013: 38 (in Russ.).

38. Vorob'ev N.I., Provorov N.A., Sviridova O.V., Pishchik V.N., Semenov A.M., Nikonov I.N. Materialy Vserossiiskogo simpoziuma «Sovremennye problemy fiziologii, ekologii $i$ biotekhnologii mikroorganizmov»/Pod redaktsiei A.I. Netrusova, N.N. Kolotilova [Proc. All-Russian symposium «Modern problems of physiology, ecology and biotechnology of microorganisms». A.I. Netrusov, N.N. Kolotilov (eds.)]. Moscow, 2014: 55 (in Russ.).

39. Vorob'ev N.I., Sviridova O.V., Kutuzova R.S. Metodicheskie rekomendatsii po ispol'zovaniyu grafanaliza $v$ issledovaniyakh biosistem, sostoyashchikh iz bioticheskikh $i$ abioticheskikh komponentov [Methodical instructions for the use of graph-analysis in studies of biosystems consisting of biotic and abiotic components]. St. Petersburg-Pushkin, 2006 (in Russ.).

40. Vorob'ev N.I., Provorov N.A., Pishchik V.N., Sviridova O.V. Programma dvukhfaktornogo dispersionnogo analiza biologicheskikh dannykh. Programma zaregistrirovana v FGU FIPS v otdele registratsii programm dlya EVM № 2014661477 ot 30.10.2014 [The program of two-factor analysis of biological data. The program is registered with FGU FIPS in the department of registration of computer programs No. 2014661477 dated 10.30.2014] (in Russ.).

41. Wang Q., Garrity G.M., Tiedje J.M., Cole J.R. Nanve bayesian classifier for rapid assignment of rRNA sequences into the new bacterial taxonomy. Appl. Environ. Microbiol., 2007, 73(16): 5261-5267 (doi: 10.1128/AEM.00062-07).

42. Ilyaletdinov A.N. Mikrobiologicheskie prevrashcheniya azotsoderzhashchikh soedinenii [Microbiological transformations of nitrogen-containing compounds]. Alma-Ata, 1976 (in Russ.).

43. Fog K. The effect of added nitrogen on the rate of decomposition of organic matter. Biological Reviews, 1988, 63(3): 433-462 (doi: 10.1111/j.1469-185X.1988.tb00725.x).

44. Bakina L.G. Rol' fraktsii gumusovykh veshchestv v pochvenno-ekologicheskikh protsessakh. Avtoreferat doktorskoi dissertatsii [The role of humic substances in soil-ecological processes. DSc. Thesis]. St. Petersburg, 2012 (in Russ.).

45. Mishustin E.N. Mikroorganizmy i plodorodie pochvy [Microorganisms and soil fertility]. Moscow, 1956 (in Russ.).

46. Bastian F., Bouziri, L., Nicolardot, B., Ranjard, L. Impact of wheat straw decomposition on successional patterns of soil microbial community structure. Soil Biology and Biochemistry, 2009, 41(2): 262-275 (doi: 10.1016/j.soilbio.2008.10.024).

47. Sun B., Wang X., Wang F., Jiang Y., Zhang X.X. Assessing the relative effects of geographic location and soil type on microbial communities associated with straw decomposition. Appl. Environ. Microbiol., 2013, 79(11): 3327-3335 (doi: 10.1128/AEM.00083-13).

48. Sait M., Davis K. E. R., Janssen P. H. Effect of $\mathrm{pH}$ on isolation and distribution of members of subdivision 1 of the phylum Acidobacteria occurring in soil. Appl. Environ. Microbiol., 2006, 72(3): 1852-1857 (doi: 10.1128/AEM.72.3.1852-1857.2006)

49. Griffiths B. S. Ritz, K., Ebblewhite, N., Dobson, G. Soil microbial community structure: effects of substrate loading rates. Soil Biology and Biochemistry, 1998, 31(1): 145-153 (doi: 10.1016/S0038-0717(98)00117-5).

50. Nicolardot B., Bouziri L., Bastian F., Ranjard L. A microcosm experiment to evaluate the influence of location and quality of plant residues on residue decomposition and genetic structure of soil microbial communities. Soil Biology and Biochemistry, 2007, 39(7): 1631-1644 (doi: 10.1016/j.soilbio.2007.01.012).

51. Kramer S., Dibbern D., Moll J., Huenninghaus M., Koller R., Krueger D., Marhan S., Urich T., Wubet T., Bonkowski M., Buscot F. Resource partitioning between bacteria, fungi, and protists in the detritusphere of an agricultural soil. Front. Microbiol., 2016, 7: 1524 (doi: 10.3389/fmicb.2016.01524). 